\title{
Experience in Supporting Industry Development in Japan and Lessons for Viet Nam
}

\author{
Nguyen Tuan Anh \\ Director, Project Management Unit, Ministry of Labor \\ 8B Ton That Thuyet Street, Cau Giay Dist, Hanoi, Vietnam \\ Email: tuananhnguyen52 [AT] gmail.com
}

\begin{abstract}
Japan is the world's 3rd largest economy with a nominal GDP of USD 5380 billion. Japan's economy has a rapid industrial development process after its defeat in World War II. Vietnam's economy in 2020 will achieve GDP growth of 2.9\%, nominal GDP of 300 billion dollars, per capita income reached \$2786, if calculated according to purchasing power parity (PPP), the average income of Vietnamese people is about \$ 8,500. In 2020, Vietnam has a trade surplus of 19.1 billion USD (an important contribution to this result is the total two-way turnover of 39.6 billion USD, a trade deficit of 1.1 billion USD from Japan. No small contribution to the economic success of Vietnam as a strategic partner of Japan - the third largest economy in the world. Japan is the first country in the G7 group to recognize Vietnam as a market economy and partner, the largest ODA sponsor for Vietnam, the number 1 investor in Vietnam and the 3rd largest trading partner of Vietnam. This paper also refers the lessons learned for Vietnam.
\end{abstract}

Keywords - Purchasing power parity (PPP), Gross Domestic product (GDP), group of 7 richest countries in the world (G7)

\section{INDUSTRIAL DEVELOPMENT POLICY OF JAPAN AFTER THE WORLD WAR II}

\begin{abstract}
The origins of modern industrial policy in Japan go back to the Meiji Restoration of the nineteenth century, when the state directed development- carried out under the slogans Shokusan-Kogyo (labor industrialization) and Fukoku-Kyohei (a wealthy country and a strong military). In particular, the unequal treaties concluded between Japan and Western power, many of which were limited in the extent of Japan's capabilities. Copy to protect domestic industries through tariffs; Japanese policymakers encourage the development of other instruments such as subsidized loans through state-managed banks. The basic wisdom of the Japanese did not come from Great Britain, but from Germany (Japan's alliance in World War II), and they, according to Friedrich List, put forward proposals to promote nascent industry, not Alfred Marshall, father of neoclassical economics.
\end{abstract}

Japan has developed a dual economy, exporting labor-intensive products such as tea, textiles and apparel while at the same time developing significant heavy industry, largely driven by Family Corporation's domination (Zaibatsu) and towards the organization of military production. Japan defeated first China (1895) (acquired Taiwan) and then Russia (1905) (finally annexed Korea) and established itself as a colony based on military might.

The state dominated the economy, which waned in the early twentieth century but the private sector was encouraged to expand. In 1950, Japan continued to implement industrial policy through taxation, non-budgetary financing, direct subsidies, credit subsidies, research and development policies, and international trade control, investment, technology import, as well as incentives of corporations and against competition with domestic enterprises. Capital is provided through the financial system and direct financial management is discouraged. In addition to formal policy tools, government officials also seek to influence through administrative orders (Gyosei Shido), coercing recalcitrant companies if necessary. These efforts were largely directed toward rebuilding heavy industry that was destroyed during the war, such as steel and transportation equipment.

\section{ECONOMIC RELATIONS BETWEEN VIETNAM AND JAPAN}

Since the early 1990s, Japan has quickly become an important partner and one of the largest markets of Vietnam. Twoway trade turnover between the two countries in 2011 reached 21.181 billion USD, of which Vietnam's exports to Japan reached 10.78 billion USD and imports reached 10.40 billion USD, so Vietnam had a trade surplus after 2 consecutive 
years of trade deficit in trade relations with Japan. In the 2011 Joint Statement, the two sides set a target to at least double bilateral trade turnover by 2020. Two-way trade turnover in the first 11 months of 2012 reached 22.5 billion USD, of which exports from Vietnam to Japan reached USD 11.9 billion (up 16.5\% over the same period in 2011), imports reached USD 10.6 billion (up $13.8 \%$ over the same period in 2011 ).

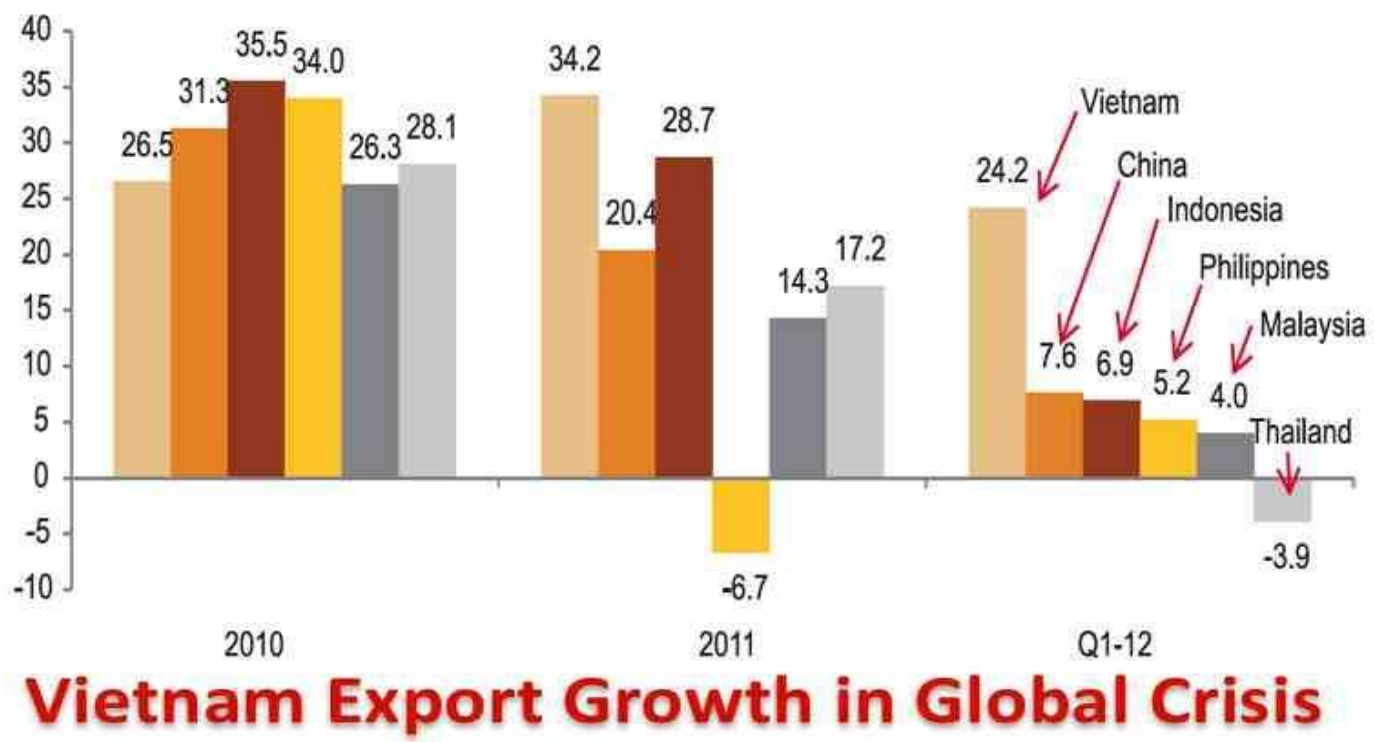

Source: EAP Economic Update, May 2012, World Bank

Figure 1. Export growth of Vietnam and other countries in the region.

(Source: World Bank)

According to chart 1, during the financial crisis, many people often mentioned the success of China, Indonesia, Malaysia and Thailand, without mentioning Vietnam. In the past, foreign investors often expected Vietnam as an Asian tiger. The financial crisis had a great impact on Vietnam, resulting in a continuous period of high double-digit inflation. Inflation in Vietnam in 2011 reached a record $18.03 \%$. However, inflation was restrained in 2012 to only $6.83 \%$. Figure 1 shows that Vietnam's export growth has always reached the highest level in the region. Vietnam's export growth in 2010 was $26.5 \%$, $34 \%$ in 2011 and $24.2 \%$ in the first quarter of 2012. According to data from the General Department of Customs in 2012, Vietnam continues to grow its exports by $18 \%$ and is expected to reach $20 \%$ in 2013 . While countries in the ASEAN region in 2012 only achieved a single export growth rate and Thailand even had negative export growth in the first quarter of 2012. China's second largest economy in the world in the first quarter of 2012 only achieved $7.6 \%$ export growth. The major contributor to Vietnam's export growth is its strategic partner Japan. Thus, it can be affirmed that the development of a strategic partnership with Japan is extremely important in stabilizing the macro-economy, controlling inflation, and sustaining growth in Vietnam in the near future.

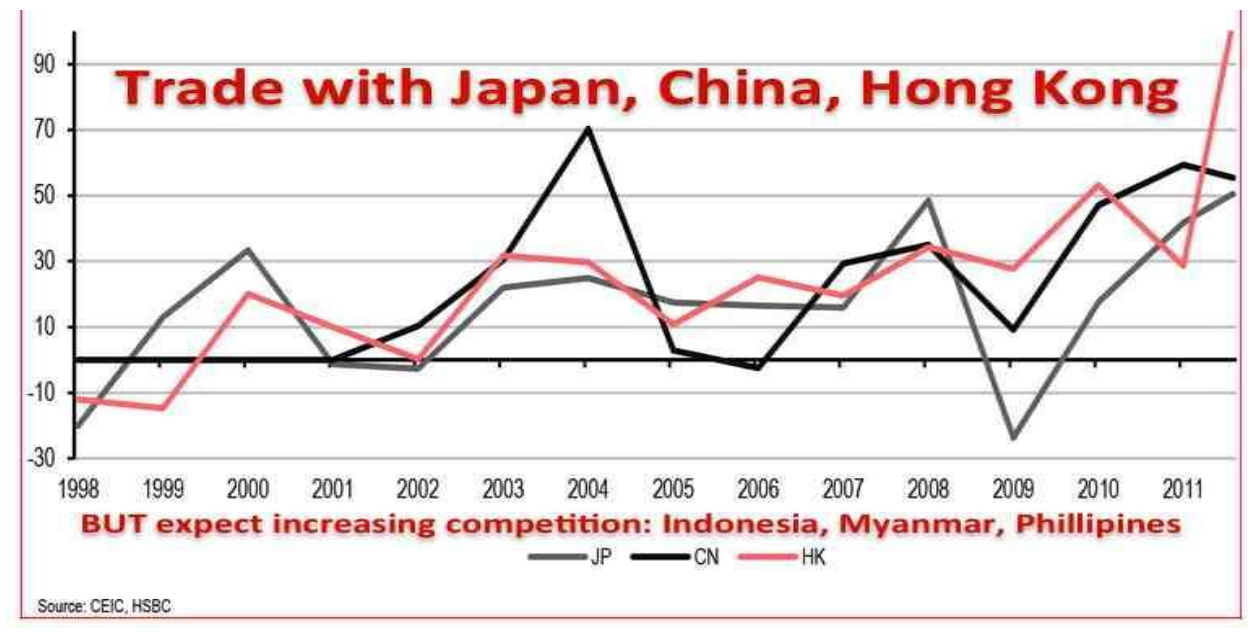

Figure 2. Vietnam's trade with Japan, China and Hong Kong

(Source: HSBC Vietnam Economic Report) 
Chart 2 shows two-way trade between Vietnam and China, Japan and Hong Kong. It can be seen that the trade between Vietnam and Japan has grown continuously over the years and the largest trade growth is $70 \%$ in $2004,50 \%$ in 2008 and 2011, especially in 2009, two-way trade decreased. about 28\%. Japan is currently Vietnam's third largest trading partner with double-digit trade growth from 2010 to present. In the coming time, Vietnam needs to continue to improve its competitiveness with Indonesia, Myanmar and the Philippines.

Japan has also risen to become Vietnam's largest investor. The two sides have completed phase IV - Vietnam-Japan Joint Initiative on improving Vietnam's investment environment and agreed to launch phase V- Joint Initiative in 2013 as of November 20, 2013. In 2012, Japan had 1,800 valid projects in Vietnam with a total registered investment of 29 billion USD, ranking first among 96 countries and territories investing in Vietnam. Particularly in 2012 (as of December 15, 2012), Japan registered 270 new projects and increased capital for 108 projects, leading with a total newly and additionally registered capital of 5.14 billion USD, accounting for $40 \%$ of total investment capital in Vietnam during the year. Thus, Japan is an important partner of Vietnam, contributing to Vietnam's economic growth.

Japan is also the largest ODA donor to Vietnam, accounting for about $30 \%$ of the total ODA commitments of the international community to Vietnam. From 1992 to 2011, Japan committed nearly 20 billion USD in ODA loans to Vietnam. First, Japan's ODA for Vietnam focuses on the goal of helping Vietnam complete industrialization and modernization by 2020. Vietnam has identified three key areas to achieve the goal, including: construction building infrastructure, training human resources and handling and restructuring state-owned enterprises. Japan has determined to support Vietnam in all three areas. Therefore, Vietnam's success in infrastructure construction, education and training, and energy development such as hydroelectricity, thermal power and nuclear is due to the great help of its strategic partner Japan. In addition to the above three areas, Japan's ODA also support Vietnam's difficulties in natural disaster prevention and response to climate change (Vietnam is one of the countries heavily affected by climate change) climate, withstand many storms, floods...) Japan also supports the construction of schools, medical stations, and social works... in remote, difficult areas of Vietnam.

Japan also has many projects to help Vietnam research, preserve and embellish typical traditional folk houses in all three regions of North-Central-South. The Japanese government began to cooperate and support the preservation of the Imperial Citadel of Thang Long in 2004 after former Prime Minister Koizumi visited and appreciated its value. In 2006, the VietnamJapan Joint Committee for the Conservation of Imperial Citadel of Thang Long was established. Since then, Japan has sent many experts on archeology to Vietnam to investigate, excavate and research. In addition, the two sides sent many delegations to visit, work, perform art, attend exhibitions, film festivals and organize festivals in each country.

In recent years, Japan has been one of the largest donors to Vietnam's Education and Training sector. According to data from the Department of Overseas Labor, Ministry of Labor, War Invalids and Social Affairs, Vietnam currently has more than 18,000 trainees studying in Japan. In 2011 alone, nearly 7,000 technical interns came to this country. Japan is a potential market for Vietnamese workers. In the period from 1992 to the end of 2008, Vietnam sent 31,000 trainees to Japan for vocational training and technical internship in fields such as electronics, mechanical processing, industrial sewing, and seafood processing, seafood, agricultural products. In recent years, Japan is still one of the markets attracting a large number of Vietnamese trainees and workers. Since 2004, Vietnam has established a Labor Management Office in Tokyo.

In recent years, local cooperation between the two countries has been strongly promoted. Some localities of the two countries have established friendly cooperative relations in many fields. Many cooperation projects between the two localities have been effectively implemented such as Osaka province supporting Ho Chi Minh City to pilot projects on clean water and environment; Fukuoka province supports Hanoi capital in the treatment of solid waste polluting water sources; Kitakyushu city supports Hai Phong city in urban planning and seaport development cooperation.

Thus, we see that the Japan-Vietnam relationship is a comprehensive strategic partnership, a model in international relations today. The continued development of this close relationship is the consistent position of the Japanese government. Mr. Shinzo Abe's first foreign visit after being elected as Prime Minister of Japan's Cabinet to Vietnam, Indonesia and Thailand has shown that this assertion is completely grounded.

Trade relations between Vietnam and Japan are constantly developing on the basis of the good friendship between the two countries. Currently, Japan is not only an important partner but also the second largest trading partner of Vietnam. Since the Japan - ASEAN Comprehensive Partnership Agreement (AJCP) took effect and especially after the two sides signed the Vietnam - Japan Bilateral Economic Partnership Agreement (VJEPA), the relationship Vietnam - Japan cooperation seems to be invigorated, promoting bilateral trade to develop more strongly. Two-way trade turnover is continuously increasing and Japan is one of Vietnam's major export markets. In the period 2011-2014, Vietnam always had a trade 
balance surplus in goods exchange with Japan. However, in the past 4 years (2015-2018), the balance of trade in goods reversed to a deficit state.

Analyzing the current situation and characteristics of the Vietnam - Japan trade relationship as well as the problems posed in the relationship between the two countries now and in the coming years, the research team of the topic affirmed, The Vietnam - Japan trade relationship will continue to grow stronger in the coming years for the following main reasons:

Firstly, the Vietnam - Japan trade relationship in the past two decades has always been in the upward development trend with the average annual increase of total import-export turnover reaching 20-30\%.

Second, Vietnam-Japan relations in general have been developed to a new height with the building of a "strategic partnership" relationship. Many documents and agreements on trade and economic partners have been signed.

Third, with the ratification of the Japan-ASEAN Bilateral Free Trade Agreement, in which Vietnam is one of the priority countries in the tariff reduction roadmap for goods imported from Japan and is allowed to enter the country. Benefiting from the fact that Japan will reduce or exempt tariffs on goods imported from ASEAN (including Vietnam), the Vietnam - Japan trade relationship will develop further in the coming years.

Fourth, along with the implementation of commitments within the framework of the WTO, not only Japan will give Vietnam preferential treatment under WTO regulations such as most favored nation (MFN) and preferential tariff regimes. Generalization (GSP) between a developed country and a developing country in bilateral trade relations, but Vietnam will also have to fulfill its commitments in market opening, transparency of legal procedures. physical.

Fifth, the Japanese market with more than 120 million people is considered a market with great potential in East Asia, especially for Vietnam's key export products such as crude oil, seafood, textiles. sewing, furniture. Sixth, in recent years, Vietnamese enterprises have made great efforts to penetrate the Japanese market by measures such as: changing the structure and quality of exports, researching the market, and promoting trade plated

\section{CURRENT DEVELOPMENT OF SUPPORT INDUSTRIES IN VIETNAM}

Mr. Masahiko Komura, a former Minister of Foreign Affairs of Japan, a member of the House, for the development of supporting industries in Vietnam, the role of small and medium-sized enterprises Japan's will be huge. Currently, there are over 200,000 Japanese small and medium enterprises that have not yet invested abroad. Thus, how to attract Japanese small and medium enterprises operating in the manufacturing industry that have not yet invested abroad to invest in Vietnam, Mr. Hideo Okubo, President - CEO of Forval Corporation Japan, and Chairman of the Special Committee to support the globalization of small and medium-sized companies Japan Business Association outlined the success points to work towards attracting investment from Japan that other countries in the region are doing. Mr. Okubo said that the development of industrial parks should go in the direction of "not only stopping as an industrial park but also integrating it into an urban area, towards small city management". Here, in addition to the area for industrial production development, there are also urban areas for housing, commercial areas, schools, restaurants, amusement parks, golf courses, hospitals, etc. future and is an absolutely necessary condition to call for investment in supporting industries of Japanese companies. Currently in Vietnam, many industrial parks focus on building infrastructure for industrial production without paying attention to surrounding urban areas. From these current situations, it shows that the development of industrial parks associated with urban areas, schools, and amusement parks has not yet received due attention from Vietnamese businesses. However, some businesses are just starting to pay attention to this problem.

The issue of factory size is also considered a criterion that small and medium-sized Japanese investors are very interested in. Industrial Park Vietnam just admiring the leasable area of large area of several hectares or workshops renting the smallest about $1,000 \mathrm{~m}^{2}$, while the needs of small and medium-sized enterprises in Japan just sub Small workshop with an area of only $300 \mathrm{~m}^{2}$. Thus, we see that Vietnamese industrial park enterprises themselves are not really interested in dividing the rental area to attract Japanese small and medium enterprises.

In Vietnam, up to now, no comprehensive survey on the supporting industry has been conducted, but to assess the current situation of the industry, we can rely on a number of survey results. Sample surveys and research are conducted by different agencies (GSO, Central Institute for Economic Management, Japan Trade Promotion Organization - JETRO and especially Vietnam Development Forum - VDF).

According to the VDF report, Japanese manufacturers believe that Vietnam's supporting industry is still underdeveloped. The localization rate of Japanese manufacturers in Vietnam was only $22.6 \%$ in 2003, while in Malaysia and Thailand it was $45 \%$ or higher. The localization rate (using locally produced industrial materials and spare parts) of Japanese companies in Vietnam by 2012 was only $28.7 \%$, much lower than that of other European countries. In other Asia, for example, the localization rate of Japanese companies in China is 59.7\%, in Thailand is 53\%, in India and Indonesia is $41 \%$, 
and in Malaysia is $39.3 \%$. According to a study by the Central Institute for Economic Management (CIEM), when conducting a survey of more than 80 FDI enterprises in Vietnam, up to 32 enterprises believe that the supply of raw materials and Vietnam's supporting economic activities are very poor. FDI enterprises very much want to coordinate with domestic suppliers to reduce production costs and improve the competitiveness of products, but it is difficult to find suitable suppliers. Sometimes, they have to find potential suppliers through phone directories or rely on personal relationships of employees, but approaching hundreds of units to find a qualified supplier.

Analyzing the situation in industrial parks, said Mr. Sakae Yoshida, Director of the Japan Trade Promotion Organization (JETRO) in Ho Chi Minh City, who has many years of contact with Japanese investors and investors in Vietnam. It is necessary to "recognize" clearly, enterprises in the field of supporting industries in Japan are currently mostly very small enterprises, with little capital, investing abroad for the first time, so they often have many concerns and concerns. They do not have money to rent a large area of land, build factories, buy equipment, etc., but they just need to rent ready-built factories for a few dozen workers. Therefore, it is necessary to have ready-built factories for rent, with an area of about $300 \mathrm{~m}^{2}$, with competitive rental prices. In order to attract businesses to support Japan, it is necessary to pay attention to providing information about the Vietnamese market, ready to advise and support them when necessary. Even issues related to language differences and shortages of human resources need to be thoroughly resolved. Japanese people are often not fluent in foreign languages, so it is necessary to support services in Japanese. However, we see that, at present, there is no industrial park that provides Japanese language training services for Vietnamese people and Vietnamese for Japanese people. In addition, Japanese life and culture have their own peculiarities; they cook and raise their children in the Japanese way. Therefore, it is required that shops, restaurants, schools ... must exist where investors live. Moreover, shops and restaurants need to be accompanied by industrial zones, with Japanese cultural style. From there, it will create an attraction for Japanese businesses to invest in Vietnam.

Specifically from the successes of industrial parks in Thailand, Indonesia, India and soon Myanmar, thus, Vietnam has taken slower steps than other countries in the region in getting ready to welcome Japanese investors. We Vietnamese have not paid enough attention to selling what Japanese investors need, but only selling what Vietnamese investors have.

Some industrial park enterprises are aware of this problem. However, it seems difficult for Vietnamese industrial park infrastructure development companies to comply with the requirements of Japanese enterprises. According to some industrial park infrastructure development enterprises, the full development of the above facilities requires infrastructure developers to have huge capital sources and must have the support of the central government and the government the locality where the industrial park is developed.

On the other hand, according to Mr. Phan Van Chinh, Head of Investment Department of Vietnam Industrial Park and Urban Development Investment Corporation (IDICO), the problem of building a factory with a size of about $300 \mathrm{~m}^{2}$ will be high. Business efficiency is very low. Building these small areas will be difficult to build fences, entrance gates, fire protection... while current regulations require each enterprise's factory in the industrial park to have a separate area. It is a fact that the cost of building small factories may be more expensive than building a large factory, but in order to attract a large number of Japanese businesses, investors should also take into account reducing its workshop area. The problem of common infrastructure development is not easy, but it is possible to combine many businesses to participate or have the support of local and even central governments. Thus, to do like the above model of successful countries is not easy and the models are specific examples that infrastructure development companies and localities have the need to attract investors, small and medium investment depending on their conditions for application and development. Currently, up to $97.3 \%$ of small and medium enterprises in Japan have not yet invested abroad. This is a great opportunity for Vietnam to attract these businesses to invest, especially after the earthquake and tsunami. Many small and medium enterprises tend to shift investment abroad to reduce disaster risks.

According to the agreement, Vietnam will conduct surveys and research on the ability to meet requirements for supporting industry investment projects from Japan in localities. Forval Group is also proposing to JICA to survey large Japanese enterprises to see which supporting industries need to be developed in Vietnam to support large investors.

"We will introduce this model in other areas so that other localities can learn from it," said Mr. Okubo, adding that a thorough survey of the local meeting conditions and industrial needs. The support of large investors will help Vietnam better attract FDI inflows from Japanese small and medium enterprises. The competent authorities of Vietnam, as well as Vietnamese enterprises, are well aware of the important role of Japanese investors.

In fact, since the beginning of 2011, Forval has researched and surveyed the ability to meet the investment needs of Japanese small and medium enterprises in Vietnam, which includes about 200 industrial parks. According to Mr. Okubo, at the present time, Forval and the Foreign Investment Agency have selected two provinces, Hai Duong and Dong Nai, to develop the model model, which focuses on two industrial parks, Dai An and Dong Nai. Nhon Trach 3. According to the 
survey results published in December 2012 by JETRO, the cost of raw materials and components accounting for the production cost in Vietnam is $61.4 \%$.

Mr. Hirokazu Yamaoka, Chief Representative of JETRO Office in Hanoi, said that reducing raw material fees is a common challenge for Japanese enterprises.

However, this is not an easy thing to do in Vietnam at the moment. According to the survey results of JETRO in 2012, the localization rate of materials and components of Japanese enterprises in Vietnam is $27.9 \%$, lower than that of China at $60.8 \%$, Thailand is $52.9 \%$, Indonesia $43.3 \%$. Thus, the localization rate of Vietnamese enterprises is still very low compared to other countries in the region. This also reduces Vietnam's competitiveness compared to Thailand, China and Indonesia. Also according to this survey, the percentage of businesses that answered will increase the localization rate at the place of investment to over $75 \%$, exceeding the rate in last year's survey of $60 \%$.

From the above analysis, it can be seen that there is a strong desire to increase the localization rate of Japanese enterprises. However, this figure also confirms Vietnam's situation of being forced to buy necessary materials and components from ASEAN countries, China and Japan. Thus, it can be seen that in order to promote exports, Vietnam needs to pay attention to increasing the localization rate by developing supporting industries. Some experts believe that the Vietnamese currency should be devalued to encourage exports, which lacks a scientific basis. If the dong depreciates, the cost of imported raw materials will also increase, not only will exports not increase, but inflation will increase. Moreover, when the dong depreciates, FDI enterprises when investing in Vietnam bring foreign currency to convert into dong for investment. The devaluation of the Vietnamese currency will discourage investors in Vietnam.

If the development of supporting industries is successful, not only Japanese multinational corporations and small and medium enterprises in Vietnam will benefit, but also large European manufacturing companies. America or Korea also benefits. Thus, companies that have invested and have major interests are important factors contributing to attracting new investors to increase investment in Vietnam.

\section{CONCLUSION AND RECOMMENDATIONS}

From the analysis of the strategic partnership between Vietnam and Japan and the importance of developing supporting industries to attract Japanese businesses to invest in Vietnam, we see that Japan is an important partner. Vietnam's leading strategic partner in the world and in the region. Strengthening the strategic partnership with Japan has always been a priority in the policy of the Vietnamese government. The strategic relationship with Japan in many aspects from economy, politics, education and training, as well as security and defense... The current situation of Vietnam's supporting industry is still underdeveloped, a reason. The important thing is that industrial park developers have not yet paid attention to the formation of urban areas, trade centers and associated services. Poor supporting industries make the localization rate of Vietnamese enterprises low. Although large Japanese enterprises have made long-term investments in Vietnam, the localization rate is only about $28 \%$. Vietnam needs to pay more attention to attracting more than 200,000 Japanese small and medium enterprises that have not yet invested abroad. In the future, we need to have some solutions as follows:

Firstly, the government needs to accelerate the creation of mechanisms and policies for the development of industrial zones attached to urban areas, hospitals, schools, and commercial centers. This is to create conditions to attract Japanese small and medium enterprises to invest in Vietnam.

Second, industrial park developers need to divide up the rental factory areas in order to create favorable conditions for small and medium Japanese investors to save costs. Especially, in the difficult context of the current real estate market, this is necessary to reduce the area of the industrial park that is vacant because there are no tenants.

Third, the government needs to strengthen cooperation with Japan in many aspects such as politics, national defense and security, education-training, economy... in order to deepen the strategic partnership between Vietnam and Japan. Japan.

Fourth, the supporting industry plays a very important role in Vietnam, especially the component manufacturing industry is a fundamental factor determining the development of other industries such as motorcycles, automobiles or the automotive industry. electronics sector - while also affecting the economy and society at large. A strong component manufacturing industry can contribute many benefits to the country such as reducing the cost of importing parts, increasing the localization rate, and improving the skills of domestic engineers, improving the quality of products and services. production efficiency, higher product value, healthier economy.

Fifth, Vietnam is one of the promising countries for Japanese investors. By 2020, Vietnam has become an industrialized country with an adequate supply of raw materials and basic fuels. The coming time will be a rare opportunity for 
industrialists to invest in Vietnam. Especially for Japanese investors who need to quickly expand their operations in Vietnam. Vietnam is being evaluated to become Asia's tiger thanks to its successes in control inflation, maintain macro stability. Vietnam's economy is becoming the world's factory.

\section{REFERENCES}

[1] “Phát triển toàn diện hơn quan hệ hệ đối tác chiến lược Việt- Nhật”, Báo Lao động, tháng 1/2013.

[2] “Tăng cường quan hệ đối tác chiến lược Việt Nam- Nhật Bản”, Báo Quân đội nhân dân, tháng 10/2010.

[3] “Tìm cách đưa công nghiệp phụ trợ Nhật Bản vào Việt Nam”, Hội nghị thu hút các doanh nghiệp vừa và nhỏ của Nhật vào các khu công nghiệp tại Việt Nam, ngày 28/2/2012 tại Tp. HCM

[4] Anjali Kumar (1997),"Theregulation of non-bank FINANCIAL INSTITUTIONS: The United States, the European Union, and OtherCountries",Discussion Paper No 362, World Bank, page 20.

[5] Audretsch, DB, and H. Yamawaki. 1988. "R\&D Rivalry, Industrial Policy, and US-Japan Trade." Review of Economics and Statistics.

[6] Auty, RM 1991. "Creating Comparative Advantage: South Korean Steel and Petrochemicals." Tijdschrift voor Economie en Social Geografie 82(1): 15-29.

[7] Baker \& McKenzie (2013), Doing Business in Thailand in 2013, Documents introduced by the Office of Bangkok, (7).

[8] Balassa, B. 1990. Economic Policies in the Pacific Area Developing Countries. London: Macmillan.

[9] Balassa, B., and M. Noland. 1988. Japan in the World Economy. Washington: Institute for International Economics. 1989. "The Changing Comparative Advantage of Japan and the United States." Journal of the Japanese and International Economies 3(2): 174-88.

[10] Baldwin, RE, and PR Krugman. 1988. "Market Access and International Competition: A Simulation Study of 16K Random Access Memories.” In Empirical Methods for International Trade, edited by R. Feenstra. MIT Press.

[11] Boss \& Young Patent \& Trademark Law Office (2013), The China Stock Exchange - IPOreview,Beijing, (8), page 13.

[12] Chen Daisong (2009), "Legal development in China: securities market khi three decades of Reform andopening$u p$ ",East China University of Political Science and Law, Documentation for the program ASLI (ASLI Visiting Fellow), Asia Law Institute, ( 8).

[13] Chiwen (2014), "Chinese securities companies: An analysis of Economic Growth", Chinese Journal ofAnalysis, (9), tr.27

[14]Đỗ Quyên, "Làm sâu sắc quan hệ đối tác chiến lược Việt - Nhật", Báo Dân trí điện tử, tháng 1/2013,

[15] Jingyun Ma, Song Fengming, Zhishu Yang (2009), "The Dual Role of the Government: securities market regulation in China 1980-2007",School of Economics and Management, Tsinghua University, China, Journal of Practice and Financial adjustment.

[16] OECD (2002), Debt Management and Government Securities Markets in the 21stCentury.

[17]Pricewaterhousecoopers, Entering the United States SecuritiesMarkets.

[18] Thu Hương, “Toàn cảnh công nghiệp hỗ trợ và công nghiệp Nhật bản”, Tạp chí Tài chính, tháng 3/2013,

[19] Triển lãm công nghiệp hỗ trợ Việt Nam "3 trong 1", Báo Tin tức - Thông tấn xã Việt Nam, ngày 28/02/2013.

[20] Xiao Chen, Chi-Wen Jevons Lee, Jing Li (2013), "ChineseTango",Government Assisted Earnings Management; School of Economics and Management, Tsinghua University, China. 